\title{
Effect of organic manures and bio-fertilizers on vegetative and floral traits of Chrysanthemum cultivars
}

\author{
Ravinder Kaur and Anurag Bajpay* \\ School of Agricultural Sciences and Technology, RIMT University, Mandi Gobindgargh (Punjab) India \\ (Email: anuragbajpai850@gmail.com)
}

\begin{abstract}
An experiment was conducted to evaluate the effect of manures and biofertilizers on three cultivars of chrysanthemum with two factor Randomized Block Design (RBD) replicated thrice, at Horticulture Research Farm of the RIMT University, Mandi Gobindgarh (Punjab). Various growth and flowering parameters were observed i.e. plant height at 45 days (cm), number of branches, number of suckers, days taken to first colour shown, days to full bloom, Flowering duration, number of flower per plant, number of cut stem per plant, diameter of flower ( $\mathrm{cm}$ ), flower weight (g), yield of flower per plant ( $\mathrm{g}$ ), yield of flower per hectare (q) for enhance farmers income. The results revealed that $\mathrm{T}_{7}($ Vermicompost $5 \mathrm{t} / \mathrm{ha}+\mathrm{PSB}+$ Azotobacter $)$ taken maximum plant height at 45 days $(50.77 \mathrm{~cm})$, respectively, maximum number of branches (5.14), number of suckers (9.99). Probing further, in floral parameters and yield, minimum number of days to first colour shown (65.90), days to full bloom (84.22) was observed in $\mathrm{T}_{7}$ (Vermicompost 5t/ha $+\mathrm{PSB}+$ Azotobacter $)$. Whereas, maximum flowering duration (32.87), number of flower per plant (40.22), number of cut stem per plant (6.88), diameter of flower $(7.14 \mathrm{~cm})$, flower weight $(4.62 \mathrm{~g})$, yield of flower per plant $(186.13 \mathrm{~g})$, yield of flower per hectare $(167.515 \mathrm{q})$ was recorded in $\mathrm{T}_{7}$. Treatment combination of Vermicompost $5 \mathrm{t} / \mathrm{ha}+\mathrm{PSB}+$ Azotobacter performed as best result treatment for foliage and floral growth inchrysanthemum
\end{abstract}

Key Words : Chrysanthemum cultivars, Manures, Biofertilizers, Growth, Flowering parameters

View Point Article : Kaur, Ravinder and Bajpay, Anurag (2021). Effect of organic manures and bio-fertilizers on vegetative and floral traits of Chrysanthemum cultivars. Internat. J. agric. Sci., 17 (2) : 130-134 DOI:10.15740/HAS/IJAS/17.2/130-134 Copyright@2021: Hind AgriHorticultural Society.

Article History : Received : 20-02-2021; Accepted :13-03.2021

\footnotetext{
*Author for correspondence:
} 